\title{
Voltaire, Diderot, Catherine II and the Russo-Turkish War of I768-1774
}

\begin{abstract}
The Russo-Turkish war of 1768-1774, provoked by the government of Louis XV, hostile to the geopolitical aims of Catherine II who sought both commercial outlets on the Black Sea and the establishment of a Greek Orthodox empire in Ottoman territory, has strongly interested enlightened Europe, in particular Voltaire and Diderot. ${ }^{1}$ France was an ally of Turkey, Sweden and Poland (all three beaten by Catherine II), which may explain the sometimes ambiguous attitude of Diderot, divided between love for his country and his support for Catherine II. The Czarina, wishing to conciliate the esteem of the writers, distributed those compliments, medals and money. They seemed to have won over to his cause, with the exception of Mably and Rousseau who were reluctant because of the question of Raynal's division of Poland, which criticized his Legislative Commission for the establishment of a new Code of Laws wrote an Instruction for her, the Nakaz), of Madame du Deffand, who criticized her ostentatious attitude. ${ }^{2}$
\end{abstract}

Keywords: Russo-Turkish war, philosophers, constantinople, ottoman empire, prisoner
Volume 3 Issue 3 - 2018

Jean Christophe Rebejkow
Academy of Créteil, France

Correspondence: Jean Christophe Rebejkow, Academy of Créteil, France, Email jean-christophe.rebejkow@ac-creteil.fr

Received: September 28, 2017 | Published: May 18, 2018

\section{Introduction}

We would like to ask questions about the conditions of this meeting. Are philosophers mere agents of Catherine II, or are there points of convergence between their ideas and those of the Empress and which ones? The analysis of the writings of Voltaire and Diderot will serve as a guide. Why privilege Voltaire and Diderot? Diderot is, along with Grimm and Falconet, the only member of the "philosophical clan" who met the Czarina. There are some echoes of this war in Diderot's work: the Memoirs for Catherine II, the Observations on the Nakaz, which he wrote at The Hague shortly before the completion of the Russo-Turkish war at the end of July 1774, reflections on the code of Catherine II, where he formulated the wish for a happy conclusion of the conflict. Diderot's daughter burned all the correspondence of her father and Grimm with the Empress of Russia during the Revolution. ${ }^{1}$ We shall consequently devote ourselves chiefly to the reactions of Voltaire, ${ }^{2}$ with whom she regularly spoke of the details of her military operations. Previously, it is necessary to briefly recall the causes of the war between Russia and the Ottoman Empire, supported by France, traditionally allied to Turkey since Francis I. The origins of the Russo-Turkish war of 1768-1774 it may seem curious to note that the nationalist uprising in Poland led to the Russo-Turkish war of 1768-74. Since the end of the Seven Years' War (1756-1763), ${ }^{3}$ Russian troops ${ }^{1}$ At least this is what Barbier says, to whom Mme. Dufour de Villeneuve (Diderot, edition of the Complete Works by J. Assézat and M. Tourneux, Garnier, 1875-1877: hereinafter AT, XX, 102). We also refer to: Diderot, Euvres complètes, edition by R. Lewinter, The French book club, 1969-1973, 15 volumes [hereinafter LEW].

${ }^{2}$ We refer to: Voltaire, Euvres complètes, éd. L. Moland, Garnier, 18771883, 52 vol.; this edition must be completed by that of his Correspondence (Paris, Gallimard, "Pléiade", [hereinafter Corr., followed by Corr., IX, 675], letters having been found since the edition Moland). The edition of the Correspondence between Catherine II and Voltaire (ed. Non Lieu, 1996), reprinting the text of the edition Bestermann, is very useful; it is preceded by a suggestive introduction by A. Stroev.

3According to Galiani, close to Diderot and the encyclopedists, it is also a stationed in Poland to protect the Orthodox minority residing there, Poland, by the perpetual treaty of March 1768, being placed somehow under Russian protectorate. The Ukrainians, allies of Russia, burnt the city of Bala, on Ottoman territory. This destruction served as a pretext for the Ottoman Empire, pushed by France, preoccupied by the expansionist aims of Russia, to declare war on October $6,1768 .{ }^{4}$ In a letter to the Comte de Vergennes, ambassador at Constantinople, the Duke de Choiseul (1719-1785), whose favorite field was foreign policy, showed himself to be concerned: "there is a disturbing situation for France in the north": is not only the expansion of Russia towards the Mediterranean, in particular, but also towards Sweden or Poland. This is a geopolitical problem. Choiseul was particularly anxious to preserve the commercial outlets of France in Turkey and he had to fight against Russia. It is therefore a commercial war, as M. de Broglie notes in a memoir on foreign policy handed over to Louis XV in 1773. ${ }^{5}$ In order to thwart Catherine II's views, Choiseul,

matter of geopolitics, Russia, to arrive at its views on Turkey, having attempted a diversion to drive away Germany and Austria. Here is what he wrote to M. Magallon, secretary of the Embassy and charge d'affaires of Spain, June 19, 1772: "Do you believe in peace with the Turk? For me, I do not believe it. Russia, in order to continue her conquests against this old empire, needed to get rid of the Prussian and the Emperor. She has found a way to do this, by throwing Poland to gnaw at them. They will bicker. Meanwhile, she will do her business. (Abbot Galiani, Correspondence, ed., L. Perey, G. Maugras, Calmann-Levy, 1881, volume 2, pp. 88-89)

${ }^{4} \mathrm{Cf}$ Albert Sorel. The Eastern Question in the Eighteenth Century, the Sharing of Poland and the Treaty of Kainardji. Paris: Plon; 1889.

${ }^{5}$ The Memoirs on foreign policy, handed over by M. de Broglie to Louis XV, confirm this commercial interest of France: "There is more, it is a war of commerce" (quoted by Mr. E. Boutaric, Unpublished secret correspondence of Louis XV, Plon, 1866, p.28). In 1788, in his Considerations on the War of the Turks with the Russians, Volney endeavored to dispel the fears of the French, who feared that Russia might harm France's commercial interests in Turkey (see his Considerations on the War of the Turks with the Turks Russians: "we procure an advantageous consumption of our merchandise [in Turkey]." Volney, in 1788, does not think that by losing the Turkish Empire, Levant ", 
who did not take account of the decline of the Ottoman Empire and the disorder of his army, suggested providing logistical assistance to Turkey: "The best way to counteract this and perhaps to expel the Empress from the throne which she has usurped, would be to provoke a war against her. Only the Turks can do this service to us. ${ }^{6}$ It will be remembered that Choiseul sent the Baron de Tott to Moustapha III to reorganize his army.

\section{Voltaire at war with Catherine II}

Between 1768 and 1774, the epistolary exchange between Voltaire and Catherine II was particularly provided. Often the letters intersect and sometimes a letter is written even before the answer to the preceding one has been received. It is not a question of retracing here the details of the military Voltaire, informed by Catherine II, but also by the press, regularly follows the course of operations; On April 1, 1769, he wrote to Catherine II: "I hear that the brave Russian troops have already beaten the Tartars.". He linked his state of health with the victories and defeats of the Russian army. In October 1769, when he learned of the victories of the Russian army, Voltaire felt himself revived. "Madame, the very old and most unworthy knight of your Imperial Majesty was overwhelmed with a thousand false rumors ${ }^{7}$ that were running and afflicting him. Suddenly there was the consoling news spread on all sides that your army had completely defeated the slaves of Moustapha towards the Dniester. I reborn, I rejuvenated, my legislator is victorious; that which establishes tolerance and which makes the arts flourish, has punished the enemies of the arts; it is victorious, it enjoys all its glory. Repetitions, the predominance of the semantic field of victory, confer its entire stamp on this passage. Voltaire insists on the triumph of the Tsarina and wishes to celebrate this victory that a French colonel, Wargemont, admirer of the Turks and undoubtedly a prisoner of Catherine II, attends his Te Deum, or rather his Te Deam, ${ }^{8}$ he will give to Ferney. Te Deam, you goddess! One finds this tone, at least sycophant, in a letter written to him shortly after, on 30.10.69, where he wishes the Czarina to be delivered from this war so that she can at last deal with internal affairs from his country. It seems that it is difficult to push the limits of flattery further, but it must not be forgotten that Voltaire has a real admiration for Catherine II and he takes several times his defense against Madame du Deffand, appreciates little. ${ }^{9}$ Voltaire will continue to show himself

nor that" the political balance of Europe would be broken at our disadvantage "(Idem, 1788, pp. 60-62). According to Theophile Lavallée, author of a History of Turkey, the Kuchouk-Kainardji , signed in July 1774, and which concluded the Russo-Turkish war of 1768-74, was not prejudicial to the commerce of France with Turkey ("It was even in the fifteen years which followed this treaty that our trade in the Levant reached its greatest prosperity "(Histoir e of Turkey, Hachette, 1859, volume II, p. 227).

${ }^{6} \mathrm{Cf}$. Hélène Carrère d'Encausse, Catherine II, A Golden Age for Russia, France Loisirs, 2003, p. 155.

${ }^{7}$ Diderot also complains of the uncertain character of the news obtained by the gazettes (to Catherine II, 17 July 1769, AT, XVIII, 315).

${ }^{8} \mathrm{On}$ the religious metaphor, cf. his letter to Catherine II of 30.10.69: "Your Imperial Majesty restores me to life, by killing Turks. [...] So I was right, I was more prophet than Mohammed: God and your victorious troops had heard me when I sang: Te Catharinam laudamus, the dominam confitemur. The angel Gabriel had thus informed me of the entire rout of the Ottoman army, of the capture of Choczin, and pointed out to me the way of Yassi. I am truly, madame, at the height of joy "(Cor. X. 23). See the Stances to the Empress of Russia on the occasion of the taking of Choczin by the Russians in 1769 (Moland, VIII, 533).

${ }^{9}$ On the sycophancy of Voltaire, we refer in particular to the following letters, all addressed to Catherine II: 20.10.70 "Victorious and legislative at the same time, you have assured immortality to your name" (Cor. X, 486); 22.1.71: "There you are, madame, in my opinion, the first power of the universe" (Cor. little avaricious of compliments on Catherine II. At the beginning of January 1770, learning that Az of was preparing galleys and brigantines to counter Moustapha at sea and that the troops of Catherine II. Had penetrated on one side to the Danube and on the other, Erzerum, his praise seems to be condemned to rehearsals: "I cannot refrain from repeating to your majesty that his project is the greatest and most astonishing that ever has been formed". The 18.5.70, sensitive to the Russian victory in Wallachia, confesses to him being unconditional of Catherine II, taking the party of Russia against the French opinion: "We are a little Mustapha in Rome and in France I am Catherine and I shall die Catherin (18.5.70, Corr., X, 259). 7.8.71, in a letter to Catherine II, he jubilant learning a Turkish defeat: "Madame is it true? Am I fortunate enough not to be deceived? Fifteen thousand Turks, either killed or taken prisoner by the Danube, at the same time as the troops of your Imperial Majesty enter the Perecop! (Cor. X. 797). A little later, resuming and turning away the last verse of his poem Le Mondain, published in 1736 ("The terrestrial paradise is where I am"), ${ }^{10}$ he exclaims: "Do you know only where was the terrestrial paradise? I know that. He is wherever Catherine II is; prostrate with me at his feet "(17.9.71, Moland, XLVII, 512).

Movements, a long and tedious undertaking, but of recalling how much Voltaire is sensitive to the information that affects the Russian armies. But the war, which Voltaire foresaw short, continues. And he, who was surprised in August 1969 that Catherine II was not supported by Austria and Prussia, returned to the charge, suggesting this time in his letter of 2 November 1772, an action by Russia and Russia Austria in the Balkans; he thinks that a victory is easy: "Some spirits say that nothing is easier than taking Bosnia, Servia and to give you a hand in Adrianople. A little later, in his letter of August 12, 1773, he was still surprised at the lack of support of the Austrian and Prussian powers. Russia finally triumphed over the Ottoman Empire in July 1774. The Treaty of Kuchuk-Kainardji, signed on 21-27 July 1774, enabled it to obtain the right of free navigation in the Black Sea and in the Straits and the Protectorate over the Orthodox Christians of the Ottoman Empire. The Crimea becomes "autonomous". Learning this success, Voltaire first rejoices in a letter to Marin of 27.8.74, where he hopes that this victory will serve as a lesson for the French: "Well! This is the Greek Church which triumphs over the Turkish Church. The autocrat had always predicted it to me. Do the Welches finally see? On 19.9.74, writing to Marin, he expressed the final regret that Greece was not yet delivered from the Turkish yoke, thanks to the joint efforts of Russia and Austria: "My Catau is very triumphant. If Joseph had wished, or rather had had money, there would be no more Turks in Europe. The country of Sophocles, Euripides and Anacreon would be free". ${ }^{11}$

\section{Voltaire's commitment to Catherine II}

Voltaire's commitment to Catherine II was expressed in two ways: on the one hand, he gave her advice, suggesting that she should use

X. 598-536); 18.10.71: where Catherine II is "the heroine of the century" (Corr., X, 842). This sycophancy should not make us forget Voltaire's real esteem for the Tsarina: "My Catau is much better than Mustapha," he wrote to Madame du Deffand on the 2.9.70 (Pléiade, Corr., X, 403) ; see also, at the same letter of 11.8.71 (Moland, XLVII, 478)

${ }^{10} \mathrm{Cf}$. the last verse of the Mondain: "The terrestrial paradise is where I am" (Moland, X, 88). This verse is reproduced in the letter to Thiériot of June 11, 1744 (Moland, XXXVI, 307).

${ }^{11}$ Catherine II does not seem to be taking too much action to help Greece to emancipate itself, cf. his letter of 22.7.-2.8.70 to Voltaire: "It depends only on the Greeks to revive Greece. I did my best to decorate the geographical maps of the Corinthian communication in Moscow. (Moland, XLVII, 160). 
chariots for her army; on the other hand, by transmitting to the Gazette de Berne, which was also broadcast in France, the information it provided on the evolution of the conflict, he was relieved of his good word. Voltaire proposes to Catherine II the tanks he had designed for the seven-year war (1756-1763), which he calls the tanks of Tomyris (sometimes also the chariots of Cyrus), named after a sovereign of the "Antiquity. ${ }^{12}$ In his letter to Catherine II of 26.2.69, when Voltaire showed himself pitiless towards the Turks ("it is not enough to humiliate them, they should be relegated for ever to Asia"), he encloses a memorandum $d$ a French officer who proposed to renew in this conflict the use of tanks of war, which had been abandoned by the ancients since the time of the Medieval war. On May 27, 1769, he returned to this proposal. In 1770, he abandoned this idea, because they are unusable in a mountainous country such as Greece.

Voltaire journalist, propagator of the ideas of Catherine II in the Gazette of Berne: In his correspondence with Voltaire, Catherine II is not sparing of information when it comes to this conflict and Voltaire is fond of it, although, what may seem paradoxical, he does not appreciate the details of the battles, as he confides in a letter to Marin of 12 May 1973: he considers that it is of no interest to anyone. But when it comes to Russian victories, the tone changes and Voltaire is the ardent propagator of the ideas of the Tsarina. The philosopher becomes a journalist. One can see traces of this activity of Voltaire in the News of various places, ${ }^{13}$ a French-language newspaper which is commonly referred to as the Gazette de Berne, ${ }^{14}$ although it never bore this title. The exchange of letters between Catherine II and Voltaire, besides reassuring the Patriarch of Ferney, enabled him to make himself the spokesman for the Czarina and to set out his views, particularly among a generally Turkish-speaking French public. Voltaire, on the other hand, did not conceal this collaboration and even asked a relative of the Czarina, Schouvalof, on 30 October 1969, to use certain passages in his letter relating to the Russo-Turkish war: let me have the interesting details of your letter put into the Gazette de Berne, which goes to France. What are the reasons for this profound attachment manifested by Voltaire and, in general, by the philosophers of the Enlightenment for Catherine II, which is accompanied by an aversion to the Ottoman Empire? We may at first think that the attitude of philosophers is dictated only by material considerations, but we shall see that this explanation proves insufficient.

\section{Material reasons}

A wise businessman, Voltaire has every interest in conciliating the good graces of the Tsarina. Following conflicting events in Geneva, he hosted a small Swiss colony of watchmakers in Ferney who had exiled to France. He proposed to the tsarina the sale of their products (essentially watches). ${ }^{15}$ Is it merely for his own sake that he does ${ }^{12}$ Tomyris, the legendary queen of the Massagetes, is known to have decapitated Cyrus the Great and plunged his head into a blood-stained overseer to avenge his son. She is considered the last queen of the Amazons.

${ }^{13}$ As early as 1788 the title became: Political News.

${ }^{14}$ Georg Sacke drew attention to Voltaire's collaboration with the Berne Gazette; he recounted his contributions for the year 1769, bringing the text of this diary closer to the correspondence of Catherine II. Cf. Georg Sacke, "Die Kaiserin Katarina II, Voltaire und die 'Berne Gazette' ', Zeitschrift für Schweizerische Geschichte, 1938, Heft 3, 305-314.

${ }^{15} \mathrm{Cf}$., in particular, his letters to Laborde 16.4.70 (Corr., X, 219); to d'Argental, Corr., X, 228; to D'Alembert, 22.6.70, Corr., X, 300; at Rulhiere, 11.7.70, Corr., X, 329, \& c. See also the letter of Catherine II. To Voltaire of August 22,1771 , in which she responded favorably to the sending of watches by the craftsmen of Ferney: "Do not scold your colonists for sending me a surplus of watches; this expense will not ruin me "(Сборник Императорского русского so? We do not think so. Indeed, it should be noted that Voltaire sold his watches to the Empress after espousing his political ideas on the question of the Russo-Turkish war, since he only collected the emigrants in 1770. Similarly, Diderot's position is not only dictated by personal interest: ${ }^{16}$ the philosopher is certainly sensitive to the invitation of Catherine II to pursue the Encyclopedia in Russia, recognizing money received in exchange for the sale of his books (it is known that Catherine II bought Diderot's library and paid him fifty years' wages in advance), ${ }^{17}$ but he will not profit for personal purposes, during his stay in Russia, from the esteem which he enjoys with her; as we shall see, ideological and geopolitical arguments seem to prevail over these considerations. ${ }^{18}$ Indeed, long before feeling the material interests they could derive from the Tsarina, philosophers shared many of his political views. Ideological reasons: the "permeability" of philosophers to the arguments of the Tsarina. The sympathy of the philosophers for the ideas of the Tsarina comes at first; it seems to us, from their satisfaction at seeing that she shares some of their ideas. There is there as the realization of an old dream, that of the philosopher-king or the philosopher-king. To understand this, it is necessary to evoke the influence of the philosophers on Catherine.

\section{The influence of the philosophers Catherine II}

Catherine II was very early influenced by the culture and the European literature, French in particular. At the announcement of the death of Voltaire, she confided her trouble to Grimm, in a letter dated the 1st of October, 1778: "Besides, it is my master [Voltaire]; it is he, or rather his works, which have formed my mind and my head." 19 But it has also claimed other philosophers of the Enlightenment, including Diderot. His instruction to the deputies for the making of a new code of laws (or Nakaz) takes up many passages from the Spirit of Laws, though sometimes subtly warping Montesquieu's thought; but it is nevertheless true that about $44 \%$ of the Nakaz is made up of borrowings from the Spirit of Laws. She therefore wished to invite among others Alembert, Voltaire, Diderot, ${ }^{20}$ as well as the Italian Beccaria, whose treatise Offenses and Punishments has furnished him with the material of a hundred articles for his Nakaz. She received at her court Frenchmen and thinkers of enlightened Europe. In the statement of article 6 of the Nakaz: Russia is a European Power, it distracts Montesquieu's theory of climates to its own advantage, thus subtracting Russia from the geopolitical principle (closely linked to its theory of climates), according to which the Asian states are subjected to despotism. If they are far from subscribing to Montesquieu's исторического общества [Collection of the Imperial Society of Russian History], hereinafter: SIRIO or Sbornik, vol.6, p.130, Moland, XLVII, 48990).

${ }^{16}$ See the letter of 9.4.74 which Diderot addressed to an unknown addressee: "You will not say that I am paid to speak thus, for I have not wanted anything from her; I gave the law on this article to the most despotable sovereign in Europe "(LEW, XI, 986).

${ }^{17}$ See Diderot's letters to Diderot in May 1766: Catherine II leaves Diderot to enjoy his library (Lew, VI, 551), and 30.10.66 (Diderot receives fifty years' pension in advance, LEW, VII, 693).

${ }^{18}$ It is more difficult to judge the case of the sculptor Falconet, who tries to have work for him and for his pupil Mademoiselle Collot, and Melchior Grimm, courtier at heart, who was looking for new subscribers to the Literary Correspondence. But it seems that Falconet, like Grimm, has a real attachment to Catherine II, as is shown by their respective correspondences.

${ }^{19}$ Letter reproduced in the Сборник [SIRIO], vol. 23, p. 102.

${ }^{20}$ Diderot recommended to him the sculptor Falconet, author of the equestrian statue of Peter I at St. Petersburg, and the physiocrat Lemercier de la Riviere. 
theses on climate, Voltaire and Diderot bluntly condemn the Turkish government.

\section{The enlightenment against obscurantism tolerance}

Catherine II is the incarnation of the enlightened sovereign in the face of Turkish obscurantism. His sympathy with the philosophers also stems from his concern to establish tolerance in his states.

\section{The enlightenment comes from the east}

Voltaire's attachment to the idea of tolerance is well known, as is shown by many of his writings: the Treatise on Tolerance of 1763, the subtitle of his plays Les Guèbres, or Tolerance, etc. He can therefore only be sensitive to Catherine II's declarations of intent in this matter, notably in a letter she wrote to him about December 22, 1767. Voltaire greets Catherine the Apostle of Tolerance in a letter of 26 February 1768 to President Henault, praising his ecumenism: the empress of Russia assembled in the great hall of her palace even Muslims, worshipers of the great lama and pagans, to form the code of laws which she was to give to an empire more vast than the Roman empire. [...] the King of Poland establishes the freedom of conscience in a country twice as large as France. The allusion to the King of Poland is an indirect way of flattering Catherine II: indeed, it is known that she installed Stanislas Poniatowski, her former lover, on the throne of Poland. Already, in his letter to Voltaire of June 29, Catherine II, citing an article in his Nakaz, emphasized tolerance, a possible echo of his reading of the Treaty of 1763 In the article Power of Questions on the Encyclopedia, which treats both temporal power and spiritual power, Voltaire takes up a passage from a letter of Catherine II dated November 28, 1765: "Tolerance is established with us; it is the law of the State; it is forbidden to persecute ". He adds: "Notice that she does not hesitate to put intolerance at the rank of faults, I almost said crimes" (idem). ${ }^{21}$ The example comes from Russia and must enlighten Europe: "Thus a despotic empress destroys persecution and slavery in the depths of the north, while in the south ..." Voltaire already writes to Galitzine, 14.8.67, that "Light is communicated on all sides". In a letter to Schouvalov, dated 30.9.67, Voltaire acknowledges this "great example of the tolerance which the Empress gives to the world", a message reproduced in a letter to Chabanon of 11.1.68: Tolerance has just been solemnly established in Poland and Russia" \& c. ${ }^{22}$ The Enlightenment comes from the East. One has the impression that it is thanks to Catherine II that they can spread.

\section{The reasons of the opposition of the philosophers to Turkey}

To this Russia enlightened by the philosophy of the Enlightenment, is opposed the obscurantism of the Ottoman Empire. This opposition is to be found in a letter to Frederick II of 31.10.69: "I stand by the princes and princesses of the North who seem to me more enlightened than the whole seraglio of Constantinople" (Cor. X. 26). We can now examine the reactions of Voltaire and Diderot towards the Ottoman

${ }^{21}$ The connection between the letter of Catherine II 22.8 .65 and the article Power has already been made in the SIRIO 17, 279.

${ }^{22} \mathrm{See}$ also a letter to Végobre, in which Voltaire praises the ecumenism of the Tsarina: "The Empress of Russia has just established universal toleration in her states, which are larger than the Roman empire. It even allows the pagan religion "(25.2.68, Corr., IX, 331, absent from Moland); Voltaire, as we shall see, will be undeceived (cf., infra, the letter to Frederick II. 15.2.75).
Empire, which seem to us somewhat emblematic of those of the Enlightenment philosophers. What image did they have of Turkey and Greece?

\section{Turkish obscurantism: Turkey and the Turks seen by the philosophers}

At the beginning of the Russo-Turkish war, in 1769, Diderot, commissioned by Grimm to give an account of Bergier's translation of the Turkish religion, laws, government and manners due to the English author Porter, condemns Turkey unequivocally: "The priests and ministers of justice, these abominable moulahs, are the barriers of despotism" (AT, IV 78-79). The Ottoman Empire, a kingdom of despotism blinded by religious obscurantism, cannot be adapted to the philosopher. This condemnation of despotism was already perceptible in the article Political Authority of the Encyclopedia, generally attributed to Diderot, in which France, a country governed by reason, was opposed to Turkey, a country which an "absolute master his whim". These positions can explain, if not understand, why, shortly after the declaration of the war, Diderot uses words of a rare violence, wishing even the extermination of the Turks, ${ }^{23}$ in his letter of May 20,1769 to Falconet: "teach me incessantly the massacre of fifty or sixty thousand Turks, if you wish to make me jump for joy." (AT, XVIII, 310). Also in 1769 , on 17 July, Diderot deplored the lack of information on this conflict, which prevented Catherine II from taking care of her people and civilizing Russia: "Will this damned war against the Turks end not soon and will any great and signal victory restore His Imperial Majesty to more important and glorious functions next year than to massacre the Turks? (AT, XVIII, 315).

This vindictive tone is shared by Voltaire. On 17.12.68, he confided to Bordes his desire to see Catherine II annihilate Turkey: "I wish passionately that she will destroy Moustapha". In July 1770 he asserted that he wished to take part in this war: "I would have at least contributed to killing you some Turks; it is said that for a Christian it is a work very agreeable to God. This does not go with my maxims of tolerance; but men are overwhelmed with contradictions and besides, your majesty turns my head. Why so much hatred? It is the correspondence of Voltaire which makes it possible to illuminate this violence of tone. Indeed, Voltaire shares this destructive will, aligning certain commonplaces against the Turks, such as inculturation and contempt for women and thus justifies their massacre by Catherine II: "It is clear that people who neglect all fine arts ${ }^{24}$ and which enclose women deserve to be exterminated. Shortly after learning of the declaration of war by Turkey, Voltaire, in his letter of November 15, 1768, gives his unconditional support to Catherine II: "It is said that Moustapha has no wit, does not like the verse, that he has never been to comedy and that he does not hear French." ${ }^{25}$ The tone is identical in the letter to Hennin of 11.1.69, in which Voltaire highlights the

${ }^{23} \mathrm{Cf}$., also, the Memoirs for Catherine II, which will take up Diderot's Russianinspired feelings: "Cursed be forever those Turks and those who have caused you this war! [The French] (Tourneux, Diderot and Catherine II, 1899, p.333) ${ }^{24} \mathrm{See}$ also his letter to Schuvalov, dated 3.12.68: "It will be fine for a woman to dethrone the barbarians who enclose women, and that the protector of science completely defeats the enemies of the fine arts." (Corr., IX, 694, Moland XLVI, 178-179). This is not a question of flattery, Voltaire issuing a similar opinion in a letter to the Princesse de Talmont of February 23, 1771 (Cor. X. 825).

${ }^{25}$ Lamartine's opinion of Moustapha III is quite different: "The empire lost one of those superior princes, by their virtues and by their enlightenment in their age, and unjustly bear before history the fault of time" (History of Turkey, Hachette, 1855, volume VII, Book 33, 413). 
stupidity and inculturation of the Turks: "I do not accustom myself to seeing Greece governed by people who can neither read nor write dance or sing. Voltaire also condemns the Turks because of their ignorance: "I will always hate the Turkish oppressors of Greece, although they have recently asked me for watches from my colony. What barbarous dishes! Sixty years ago, they were sent watches from Geneva and they have not yet known how to make them. They do not even know how to regulate". These ideas were taken up by Volney in 1788. The image of the Turks characterized by their "obstinacy of prejudice", their "depth of ignorance" and their "constancy of absurdity" is to be found in Volney (see his Considerations on war of the Turks with the Russians, 1788, p.15). Voltaire opposes the obscurantism of Turkey to the lights of Greece, the mother of science and the arts. Greece is for him, therefore, the historical reference, the model and we understand that he shares with Catherine II this desire to see a Greek Orthodox empire re-emerge on the ruins of the Turkish Empire, with Constantinople as its capital. ${ }^{26}$

\section{Delivering Greece from the yoke of Turkish obscurantism}

If it is a leit-motiv that Voltaire develops in his correspondence concerning the Russo-Turkish war of 1768-1774, it is indeed that of liberating Greece from the yoke of the Ottoman oppressor. He is particularly interested in the news concerning the progress of the Russian armies in Greece. His letter to Schuvalov, dated 3.12.68, shows his confidence, his desire to fight with the Turkish enemy and to deliver Greece: "The fine moment, sir, that when Greece would see her shackles broken! [...] Your armies have beaten armies more disciplined than the Janissaries. You have already taken the Crimea, why should you not take Thrace? In a letter to Frederick II of 20 August, 70, he deplores a Russian defeat which affects that country which is dear to him: "Providence, in order to reduce my pride, which would swell with so many favors, taken over Greece; at least it allows the gazettes to say so. It is a very fatal blow to me. [...] you know what a feast I was to see the grandchildren of the Sophocles and the Demosthenes delivered from an ignorant one. At the end of July 1770, learning that Catherine II had liberated the Peloponnesus, he rejoiced and was particularly concerned about the fate of the Greeks in the event of Russia's victory: "If you make peace, I am sure that it will be that you will preserve Moldavia, Wallachia, Azof and navigation on the Black Sea, at least as far as Trebisonde. But what will become of my poor Greeks? What will become of the new legions of Sparta?. ${ }^{27}$ Voltaire deplores the fact that the Turks occupy and sack the land of Homer, as he wrote to the Princess de Talmont on February 23, 1771: "I shall always have a tooth against people who have devastated, impoverished and brutalized the whole of Greece. ${ }^{28}$ $\mathrm{He}$ is sorry to see the Turks thus despising the cultural heritage of Greece: "I am always distressed to see a basque trample underfoot the ashes of Themistocles and Alcibiades". Voltaire's considerations

\footnotetext{
${ }^{26}$ There was a great Orthodox community in Constantinople, as the Essay on Manners (Moland, XII, 103) recalls.

${ }^{27}$ See also the letter to Catherine II of 12.10 .70 , in which Voltaire complained of the Greeks: "May your Majesty permit me only to pity these poor Greeks, who have the misfortune of still belonging to people who speak Turkish. (Cor. X. 440). He again worries about the fate of Greece on 30.7.71 in a letter to Catherine II, in close terms (Corr., X, 791).

${ }^{28} \mathrm{Cf}$. d'Alembert, 4.9.69: "The affairs of the Turks go wrong. I would have liked to see these scoundrels expelled from the country of Pericles and Plato. It is true that they are not persecutors, but they are brutalizers. "(Corinthians 9: 1071).
}

are therefore mainly explained by the fact that he takes strongly the cultural heritage of Greece, ${ }^{29}$ especially as regards Greek literature, whereas he considers the Turks as ignorant; ${ }^{30}$ he thus justifies in his letter of 2.11 .71 his desire to see Greece liberated from the Turkish yoke: "this gives me hopes for Athens". For Voltaire, attached as Catherine II to the idea of tolerance, the question of religion becomes secondary, what is more important is the rebirth of Greece. Thus it can only share the views of Catherine II, who advocates the destruction of the Ottoman Empire and the revival of the Greek Orthodox Empire ${ }^{31}$ with Constantinople as its capital - and later dreamed of installing her grandson Constantine (1779-1831) on the throne. According to these lines addressed to the tsarina on 26.11.70, Voltaire is not opposed to the dream of Catherine II: "we must prefer Greeks, though schismatic, to Mohammedans. Attempts to mediate a peace treaty between Russia and Turkey led by France or Prussia by Frederick II hampered Voltaire, for they seemed to disregard the fate of Greece, which he desired to free from the Turkish yoke. In 1773, establishing a parallel between the Russians and the Greeks and lambasting the stupidity of the Turks, he placed his confidence in Catherine II: "I see that the Russians have good spirit and good spirit. Your Imperial Majesty was not made to rule fools, which always made me think that nature had destined him to reign over Greece. The proposals for peace - those of Frederick II; those of the French government which, as we shall see, attempted to associate Diderot with it-met with little success in Voltaire. He warns the tsarina against a sloppy peace and this letter of 13 February 1773 takes on the premonitory accents, announcing the future Russian-Turkish war of 1787-1792.

But apart from attachment to Greece, the mother of the arts and the home of tolerance and enlightenment, Voltaire emphasizes that his position in favor of Russia is also determined by economic considerations; he would like the court of Prussia to associate itself with the courts of Austria and Russia in order to triumph over the Ottoman Empire in order to exploit the resources of the Turkish soil: "It is because the Turks have very good wheat and no fine arts, that I wished to see you share Turkey with your two associates". Diderot also sided with the Tsarina for reasons close to those of Voltaire; we must not expect an atheist to advocate the Orthodox religion, but, at least if he remains silent on this point, he agrees with Voltaire in that he opposes, like him, the lights from Greece to Turkish obscurantism. In fact, the Memoirs of Grimm relate this scene between the philosopher and the Empress: "The Empress Catherine, some years before, had made Greece insurgent.... Diderot was enchanted; he dreamed of nothing but the enfranchisement of Greece; he saw renewed between their ruins Athens and Sparta. ${ }^{32}$ "Moreover, it is known that Diderot saw in the Greeks enemies of despotism and tyranny (AT, XV, 59).

${ }^{29}$ Voltaire considered his predilection for Greece as a prejudice; he confesses to Frederick II. "Try, I beg of you, sire, to have pity on my old prejudices in favor of the Greeks against the Turks" (Cor. x, 283). In other words, he admits at first that his taste for Greece is somewhat irrational, since "Prejudice is an opinion without judgment" (Moland, XX, 264).

${ }^{30} \mathrm{Cf}$., also his letter to Schuvalov of 15.10.73: "Some Frenchmen ask me why I take the side of the Russians against the Turks. I tell them that when the Turks have an Empress like Catherine II., And that there will be at the Ottoman Porte chamberlains like the Count de Schouvalow, then I shall become a Turk. "(Cor. $\mathrm{Xi}$.

31In Article 351 of the Nakaz, Catherine II affirms her faith in the Orthodox religion

${ }^{32} \mathrm{Cf}$. Melchior Grimm, Unpublished political and anecdotal memoirs of the Baron de Grimm from the year 1743, to 1789, Paris, Rouge-Wolff, 1830, 2 volumes, volume 2, 232: the memories are apocryphal; anecdote seems plausible. 
Thus, Voltaire and Diderot present themselves as allies of Catherine II. But their attitude is not one, homogeneous. Diderot and probably Grimm, also, in 1773, set to work for an honorable peace between Turkey and Russia, in order to preserve French interests.

\section{Diderot, grimm: double agents? espionage and diplomacy}

Durand de Distroff, French ambassador to Russia, observing the prestige Diderot enjoyed with the Czarina, wrote to the Comte d'Aiguillon, the French Minister of Foreign Affairs, who succeeded Choiseul: "I told M. Diderot what I was expecting a French. He has promised to efface, if possible, the prejudices of this princess against us". On 15 February 1975 Durand wrote to his minister: "I have proof that Mr. Diderot and Mr. Grimm have behaved as I have desired", which shows that they were solicited to serve national interests. Double play for Grimm certainly but for Diderot too, durand de Distroff, writes, always to the same interlocutor, that "M. Diderot undertook to deliver to M. de Noailles [French Minister in Holland] a package containing several states relating to the commerce of Russia and a map of the a black sea that is all the more interesting because ... the fortresses to be created at the mouth of the Don have been designated there, ignored or badly rendered on the engraved maps. I owe to Mr. Denon the copy of this card". Dominique Vivant Denon was then attached to the embassy in Russia. Is Durand's use of the word "took charge" suggest that the philosopher proposed to pass to France the plans copied by Vivant Denon, then a young embassy attaché in Russia? But did the philosopher accept spontaneously before the demand that was made to him, or did he yield to the pressure?

There is a sincere admiration on the part of Diderot for Catherine II and a real affinity of Grimm with the Czarina, as is proved by the letters of Catherine II. To Grimm (published in the Collection of the Imperial Society of Russian History or SIRIO, tomes 23 and 44); there is also a real convergence of views on the question of Turkey and that of Greece; but perhaps they were compelled to submit to the views of the French Government? It is certain that Diderot also served as an intermediary to transmit to the Empress proposals for peace. Diderot at first appeared to have refused to act as intermediary, as indicated in the letter of 12/20 November 1773, from Sir Robert Gunning to the Earl of Suffolk: "Count Panin, said, in great confidence and under the seal of secrecy, that M. Diderot, who had his free entry to the Empress, had been solicited by M. Durand to hand over to the Sovereign a paper containing proposals for peace with the Turkey, proposals which the Court of France agrees to have accepted if its good offices are accepted. M. Diderot strongly forbade himself to leave his sphere and expose himself to being shut up in the Bastille on his return and he absolutely refused to accede to the desire of the French minister. ", pp. 383, also reproduced in LEW, X, 1100-1101). But Durand certainly found the words to convince Diderot. A little-known letter of 23 November 1973 from Prince Lobkowitz to Prince Kaunitz, Austrian Minister for Foreign Affairs, relates that the philosopher transmitted a memorial to the Czarina in order to convince him of the arguments which Durand had twice attempted to expose to Panine; but this attempt was not successful, the Tsarina having thrown this memory into the fire, in the presence of Diderot. ${ }^{33}$ The letter of Sir Robert Gunning, Chargé

${ }^{33} \mathrm{Cf}$. la lettre du prince Lobkowitz, au prince Kaunitz: "After reading this, the Empress will be thrown into the fire in the presence of Diderot" (23.11.73, SIRIO 125, p.288). d'affaires of England in Russia, to the Earl of Suffolk, of 3.12.73, indicates that Diderot knew how to appease the fury of Catherine II, teaching the mission whose philosopher was commissioned by the government. ${ }^{34}$ Durand, however, was not put off and waited for a more propitious occasion, as suggested in Lobkowitz's letter of 29.1.74. ${ }^{35}$

Diderot, the philosopher of the Memoirs for Catherine II, confirms that Diderot attempted (at the instigation of Durand?) To expose Catherine II, the reasons for an approchement between France and France Russia: "Who is winning now in your war with the Turks? It is not France. [...] I believe her infinitely more disposed to ally with your Majesty than with Prussia". ${ }^{36}$ Unlike Voltaire, who advocates an alliance between Austria, Prussia and Russia, Diderot counsels Catherine II to beware of Frederick II. In a letter to Dr. Clerc of April 8, 1774, Diderot told him of his patriotism and justified it thus: "As to the article of the governments, it would be quite foolish to speak ill of that of a country where one proposes to spend the rest of his life; not to mention that I am a good Frenchman, by no means rebellious"; which, in a letter of 12 September 1974 to Catherine II, did not prevent him from rejoicing at the peace concluded between the Russians and the Turks by the Treaty of Kuchouk-Kainardji at the end of July 1774 "as a man, a philosopher and as a Russian, for I have become so by the ingratitude of my country and by your kindness". The attachment for his country and perhaps the pressure of the ambassador on the one hand and the admiration for Catherine II on the other, make it possible to understand these acts of Diderot, which may seem contradictory. Like Voltaire, Diderot wished to express his gratitude to the Tsarina. He praises the action of Catherine II and his conception of the role of the sovereign joins here the voluntary one of the action of the great man: "It is not great bodies, great men do great things. The weak people become strong under illustrious leaders. Strong people are reduced to nothing under stupid and idle masters "(idem). One can see in these lines nostalgia for the philosopher king or the philosopherking.

Like Voltaire's, Voltaire's attitude towards Catherine II is ambiguous. Voltaire certainly did not play spies on behalf of the French government, but he distanced himself from the Czarina. Indeed, in his letter to D'Alembert of 25 February 1975, Voltaire wrote to D'Alembert that he "counted neither on any satrap nor on any monarch of the East". He is surprised that the posthumous work of Helvetius (of man, his intellectual faculties and his education) is dedicated to Catherine II, "the most despotic power on earth" Alembert, 26 June 1773, Corr., XI, 390). Voltaire admits in a letter of 15.2.75 to Frederick II his final disappointment at the action of Catherine II: "I was caught like a fool when I believed before the

34"Notwithstanding the manner in which Mr Panin assured me the Empress received the paper Mr. Diderot gave her from the French minister, he (Mr. Diderot) is at present with her at Zarko Selo, a proof that he found out the means of appeasing her anger" (3.12.73, SIRIO 19, p. 389).

${ }^{35} \mathrm{Cf}$. la lettre du prince Lobkowitz, au prince Kaunitz: "in the meantime, Durand cannot be deterred, and is only waiting for a good opportunity to make new attempts" (SIRIO 125, p. 309, lettre du 29.1.74).

${ }^{36}$ In this page of the Memoirs for Catherine II, Diderot warns the Tsarina against the Prussian intrigues. See on this subject the letter of Durand de Distroff to the Duke of Aiguillon, of December 31, 1973: "He [Diderot] told me, and I have reason to believe that it is not false, he painted the danger of the alliance of Russia with the King of Prussia, and the utility of ours. The Empress, far from blaming this liberty, has encouraged her by her gestures and her words. His residence and conversations with the Empress disturb the Count of Solms, and displease M. de Lobkowitz [Minister of Austria] "(Lew X, 1120). 
Turks' war that the Empress of Russia with the King of Poland, to have justice done to the dissenters and to establish only freedom of conscience. You kings, you give us good to guard; you are like the gods of Homer, who make men serve their purposes, without these poor people suspecting it". The sincerity of this confession is striking. As a well-informed businessman, Voltaire sold watches to Catherine II, but also to the enemies of the Czarina, like this "big pig" of Mustapha (the expression appears in a letter to Catherine II, February 1769) or as the Cardinal de Bernis. On the 4.6.70, Voltaire begged Argental to intercede in favor of his business. His interest in Russia is thus also dictated by a commercial interest: "I am interested in Russia, as you know; our colony sends many watches". He admits that his contempt for Turkey and his interest in Greece would not prevent him from entering into commercial relations with the Ottoman Empire in the event of his victory: "I passionately wished that the [Turks] chased from Europe, because they have enslaved the descendants of the Alcibiades and the Sophocles. I hear that these circumcised men have taken up the Peloponnesus; in this case, I will reconcile myself with them, for I have established, from the ruins of Geneva, a small society which is strongly connected with Constantinople".

France, worried about the geopolitical aims of Catherine II, urged the Ottoman Empire to declare war on her in 1768. In her war of 1768-74, which was considered the origin of the Eastern Question, Catherine He dreams of reviving a great Greek Orthodox empire, but this war is also a trade war. The Tsarina tries to reconcile the opinion of the philosophers (Voltaire, Diderot...) and of their friends, in order to influence French opinion. Voltaire is also one of her masters to think and she does not hesitate to say that she shares her views, on tolerance in particular. The reasons for this attachment of Catherine II were also dictated by a concern for propaganda: she kept Voltaire very regularly informed of the state of the conflict and especially of the advances of the Russian army. Did she manipulate or even subsidize Voltaire so that in his conversations or in his writings he praised the action of the Tsarina? There are no traces of it. What is certain is that it has exercised a certain influence on Voltaire, if only because we find echoes of the letters of Catherine II. To Voltaire in the Gazette de Berne, a gazette of which the Czarina and the philosopher knew that it was distributed and read in France.

One may think that the attitude of philosophers is dictated only by interest; but this opinion must be strongly qualified. From the beginning of the conflict, Voltaire took up the cause of Catherine II. He made a commitment to the Czarina, long before he was a prudent businessman and offered to buy watches made in Fernery. What are the reasons for this attachment? The Ottoman Empire is, for Voltaire as well as for Diderot, a symbol of obscurantism. To this obscurantism is opposed the enlightenment of Catherine II. Russia and the desire that she revive Greece, mother of the arts, in her crusade against the Turks: The Greek Orthodox Empire, which the tsarina will found, illuminated by the philosophy of the Enlightenment, will have to set an example for the sovereigns of Europe. Indeed, Voltaire is sensitive to the ideas advocated by Catherine II with regard to tolerance, in particular, which prolong and amplify her own reflections. The Enlightenment came from the East, Voltaire thus dreams of a Russian and a Greek empire founded on the ruins of the Ottoman Empire, where tolerance and freedom would reign under the aegis of Catherine II. It does not matter to Voltaire that the war waged by Catherine II is, in the name of the Enlightenment, a crusade to defend the Orthodox Church, the important thing is for him to resuscitate Greater Greece. Diderot, if we are to believe Grimm's testimony, seems to agree with him on this point.

\section{Conclusion}

This struggle against obscurantism explains Voltaire's vindictive spirit, which proposes to Catherine II the chariots he had designed for the seven-year war (1756-1763). Voltaire's political ideas thus echoed those of Catherine II or suggested certain political proposals of the Czarina, as regards Turkey. Voltaire's esteem for Catherine II did not prevent him, as a prudent businessman, from hoping for peace so that he could more easily sell his watches to the Ottoman Porte, just as Diderot's admiration did not prevent him not to act for the interests of his country. On his return to France he took charge of the plans copied by Vivant Denon, which included the location of the Russian fortresses to be created at the mouth of the Don. Voltaire and Diderot joined the Czarina, mainly for ideological reasons, but also for recognition. Diderot expresses this very well in his letter of 14.9.74, but also in a letter to Falconet of 1767 and in a letter to Sophie Volland, where he uneasily contemplates a trip to thank the tsarina of his bounties. Voltaire writes in a letter to Richelieu, dated the 3rd of July, 71: I have detested in all my passions the vice of ingratitude; and if I had an obligation to the devil, I would say well of his horns.

\section{Acknowledgements}

None.

\section{Conflict of interest}

Author declares that there is no conflict of interest. 